\title{
РОЗРОБКА ТА ДОСЛІДЖЕННЯ ІМІТАЦИЙНОЇ МОДЕЛІ ПРОЦЕСУ ТЕРМОВАКУУМНОЇ ОБРОБКИ ХАРЧОВИХ ПРОДУКТІВ ЯК ОБ'СКТУ КЕРУВАННЯ
}

\author{
О. В. Мазур ${ }^{1}$, К. Є. Грабанова ${ }^{2}$, С. С. Гудзь ${ }^{3}$ \\ ${ }^{123}$ Одеська національна академія харчових технологій, м. Одеса, Україна \\ ORCID: ${ }^{1} 0000-0001-7104-9010,{ }^{2} 0000-0002-7976-5625$. \\ E-mail: ${ }^{1}$ mazur.a.v.ua@gmail.com, ${ }^{2} 2911$ cat2q@gmail.com, ${ }^{3}$ sergogudz@gmail.com
}

Copyright (C) 2020 by author and the journal "Automation of technological and business - processes. This work is licensed under the Creative Commons Attribution International License (CC BY). http://creativecommons.org/licanses/by/4.0

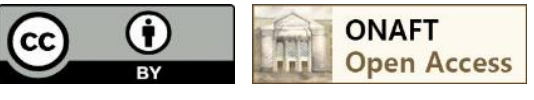

DOI: https://doi.org/10.15673/atbp.v12i1.1708

\begin{abstract}
Анотація. Перевагою теплової обробки харчових продуктів в вакуумі є можливість реалізації процесів в бескисневому середовищі. Теплова обробка в таких умовах сприяє збереженню поживних речовин, вітамінів, антиоксидантів, фарбувальних пігментів сировини, смакових якостей і т.п., а також збільшенню терміну застосування допоміжних речовин і зберігання готових продуктів в порівнянні з обробкою при атмосферному тиску. Роботу присвячено побудові імітаційної моделі процесу теплової обробки харчових продуктів в вакуумному термоелектричному котлоагрегаті. Проведено аналіз технологічного процесу як об'єкту керування. Виконана декомпозиція технологічного процесу на окремі субпроцеси та розроблена його загальна структура 3 основними взаємозв'язками між моделями окремих вузлів. Розроблено моделі термоелектричного перетворювача, пароводяної сорочки, випарника, паропроводу, конденсатора, радіатора з повітряним охолодженням, вакуумної системи, збірника конденсата, . Ці моделі, а також загальна імітаційна модель процесу реалізовані в середовищі Matlab Simulink. Для перевірки імітаційної моделі технологічного процесу термовакуумної обробки на адекватність проведені іiі тестові дослідження як об’єкту керування. В статті наведені отримані в ході проведених віртуальних експериментів, квазістатичні та динамічні характеристики процесу за основними каналами перетворень. Результати тестування імітаційної моделі процесу теплової обробки харчових продуктів в вакуумі як обєкту керування свідчать про те, що вона досить адекватно відтворює основні параметри складних теплових та тепломасообміних процесів, що протікають в малогабаритному вакуумному термоелектричному котлоагрегаті, i може бути використана при дослідженнях його як об'єкту керування, а також при розробці та тестуванні алгоритмів керування процесом.

Abstract. The advantage of heat treatment of food in vacuum is the ability to implement processes in an oxygen-free environment. Heat treatment in such conditions helps to preserve nutrients, vitamins, antioxidants, color pigments of raw materials, taste qualities, etc., as well as increase the life of auxiliary substances and storage of finished products compared to processing at atmospheric pressure. The paper is devoted to the construction of a simulation model of the process of heat treatment of food in a vacuum thermoelectric boiler. The process as an object of control is analyzed. The process was decomposed into separate subprocesses and its general structure was developed, with the main interconnections between models of individual nodes. Models of thermoelectric transducer, steam jacket, evaporator, steam line, condenser, radiator with air cooling, vacuum system, condensate collector have been developed. These models as well as general simulation model of the process have been developed in Matlab Simulink environment. To check the developed model for adequacy, test studies of the process as a control object have been carried out.The article presents the quasi-static and dynamic characteristics of the process by main transformation channels obtained in the course of the conducted virtual experiments. The results of testing a simulation model of the process of heat treatment of food in vacuum as an object of control indicate that it adequately reproduces the complex thermal and heat transfer processes occurring in a small vacuum thermoelectric boiler, and can be used as an object of study as well as upon developing and testing process control algorithms.
\end{abstract}

Ключові слова: термоелектричний, вакуумний, теплові процеси, харчові продукти, термовакуумна обробка, варка, уварювання, випарювання, екстрагування, маринування, сушка, жаріння, безкисневе середовище, технологична схема, анлітична модель, імітаційне моделювання, квазістатичні характеристики, ідентифікація, система автоматичного керування.

Keywords: thermoelectric, vacuum, thermal processes, food products, thermal vacuum treatment, cooking, boiling, evaporation, extraction, pickling, drying, frying, oxygen-free environment, flow chart, analytical model, simulation, quasistatic characteristics, identification, automatic control system 


\section{1. Вступ}

Перевагою обробки харчових продуктів в вакуумі є можливість реалізації процесів в безкисневому середовищі, що в значній мірі сприяє збереженню поживних речовин, фарбувальних пігментів сировини і смакових якостей, збільшенню терміну зберігання готових продуктів в порівнянні 3 обробкою в повітряному середовищі. Малогабаритний вакуумний термоелектричний котлоагрегат (МВТК), призначений для реалізації процесів варки, уварювання, випарювання, екстрагування, маринування, сушки, жаріння і т.п. в безкисневому середовищі . Він може бути застосований в кулінарії для різних видів кулінарної обробки харчових продуктів, в харчовій промисловості для виробництва джемів, конфітюрів, варення, дитячого харчування, пюре фруктових та овочевих, а також в фармацевтичній або парфумерній промисловості.

\section{2. Аналіз літературних даних і постановка проблеми}

Процеси теплової обробки широко застосовуються при приготуванні продуктів в харчовій промисловості та кулінарії. Це складні тепломасообмінні процеси, які реалізуються з використанням різних середовищ, що передають тепло для надання цілеспрямованого впливу 3 метою отримання необхідних фізико-хімічних і органолептичних властивостей харчовим продуктам $[1,4]$. При цьому для підведення та відведення тепла можуть застосовуватися рідке середовище (вода, жир, і ін.), контактний нагрів, водяна пара, пароповітряна або пароводяна суміш, електромагнітне випромінювання НВЧ і ІЧ діапазонів або комбіноване використання декількох 3 цих середовищ. Згідно 3 .[2] основними процесами теплової обробки продуктів є варіння і смаження. При цьому вони можуть реалізовуватись 3 безліччю температурних, барометричних та часових режимів, які і визначають їх різноманітність. Реалізація цих процесів 3 використанням вакуумних технологій дозволяє проводити теплову обробку продуктів в бескисневому середовищі в широкому діапазоні температур, використовуючи при приготуванні продуктів в якості додаткового впливу дінамічну зміну тиску [3]. Для реалізації таких процесів в МВТК з можливістю динамічної зміни параметрів в часі актуальним є дослідження їх як об’єктів керування.

\section{3. Мета та задачі дослідження}

Метою роботи є дослідження процесу теплової обробки харчових продуктів в МВТК як обєкту керування. Для досягнення мети необхідно вирішити наступні задачі:

1. Провести аналіз технологічного процесу термовакуумної обробки харчових продуктів в МВТК та визначити основні регламенти його ведення.

2. Розробити аналітичну імітаційну модель процесу в МВТК та реалізувати її в середовищі Mathlab Simulink.

3. Провести імітаційне моделювання та отримати квазістатичні і динамічні характеристики процесу в МВТК за основними каналами керування .

\section{4. Аналіз технологічного процесу термовакуумної обробки}

МВТК призначений для теплової обробки продуктів в безкисневому середовищі при тиску від 50 до 2500 Мбар та температурі від 30 до $120{ }^{\circ} \mathrm{C}$. Технологічну схему МВТК наведено на рис. 1.

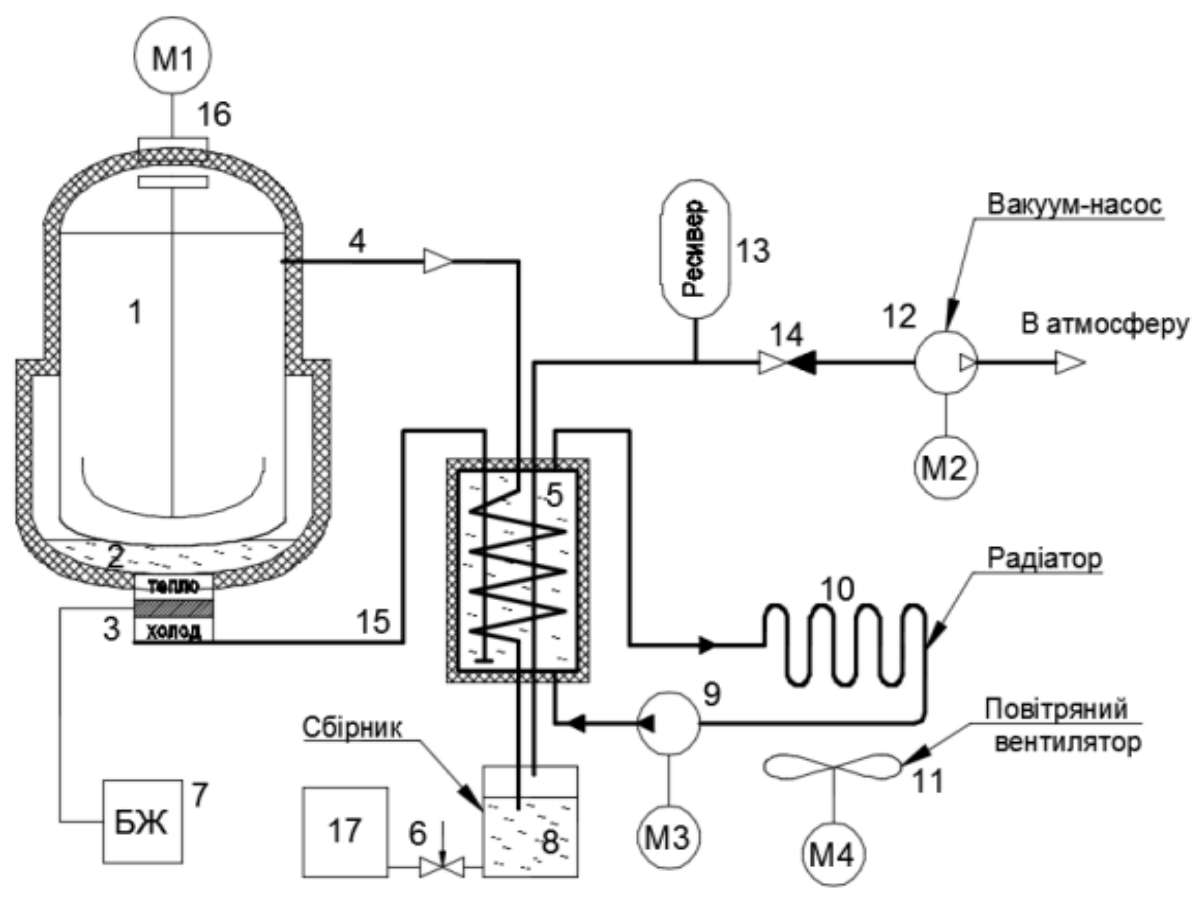

Рис. 1 - Технологічна схема МВТК 
http://www.atbp.onaft.edu.ua/

Позначення до рисунку 1: 1 - випарник, 2 - парова сорочка нагріву, 3 - термоелектричний тепловий насос, 4 -паропровід сокових парів, 5 - водяний конденсатор, 6 - кран вентильний, 7 - регульований блок живлення, 8 - збірник конденсату, 9 - циркуляційний насос, 10 - радіатор, 11 - вентилятор, 12 - вакуумний насос, 13 - ресивер, 14 -3воротний клапан, 15 - теплова труба, 16 - мішалка, 17 - додаткова ємність.

Для реалізації технологічного процесу необхідно підтримувати заданий рівень тиску в вакуумній системі, здійснювати підвід тепла до випарника 1, та відводити надлишкове тепло 3 водяного конденсатору сокових парів 5 підтримуючи в них заданий тиск. В якості нагрівача і охолоджувача застосовано термоелектричний тепловий насос 3 , який складається 3 декількох термоелектричних перетворювачів (ТЕП). "Гаряча" сторона модулів ТЕП охолоджується за рахунок підігріву пароводяної сорочки 2 вакуум-апарата для підводу до нього тепла. "Холодна" сторона модулів ТЕП приєднана до теплової труби 15 охолоджує конденсатор 5. Використання ТЕП дозволяє заощаджувати енергію, яка витрачається на випаровування води 3 продукту та конденсацію сокових парів. В якості конденсатора 5 застосовано змісвиковий теплообмінник, до якого для відводу тепла прикріплені теплова труба та водяний контур охолодження 9 -11. Вакуумній насос 12 підключено до збірника конденсату 8 за допомогою вакуумної системи, до якої входить ресивер 13 та зворотній клапан 14.

\section{5. Загальна структури моделі процесу}

Перед розробкою імітаційної математичної моделі в цілому згідно 3 [5] виконаємо декомпозицію технологічної установки на окремі вузли і розглянемо загальну структуру процесу з основними взаємозв'язками між моделями окремих вузлів. Результат такої декомпозиції представлено на рисунку 2.

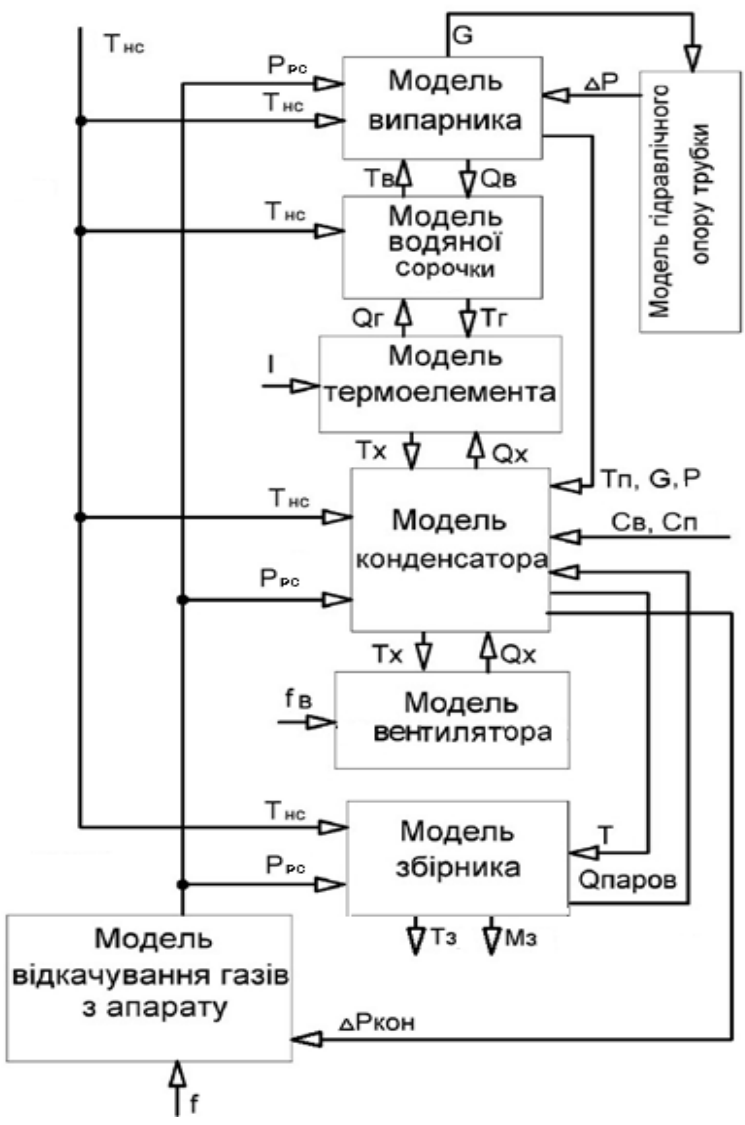

Рис. 2 - Структурна схема моделі процесу

На структурній схемі процесу термовакуумної обробки харчових продуктів прийнято наступні позначення: $\mathrm{G}-$ масові витрати продукту; $\Delta \mathrm{P}$ - різниця тиску між випарником та конденсатором; $\Delta$ Ркон - приріст тиску в системі при неповному конденсуванні парів; Ррс - тиск в ресивері; Р - тиск у випарнику; Т - температура "гарячо"ї сторони ТЕП; $\mathrm{Q}_{\mathrm{r}}$ - тепловий потік від "гарячої" сторони ТЕП; $\mathrm{T}_{\text {в }}$ - температура води у води у паровій сорочці; $\mathrm{Q}_{\text {в }}-$ тепловий потік на випаровування води; $\mathrm{T}_{\mathrm{x}}$ - температура "холодної" сторони ТЕП; $\mathrm{Q}_{\mathrm{x}}$ - тепловий потік від "холодної" сторони ТЕП; $\mathrm{T}_{\mathrm{r}}$ - температура радіатора; $\mathrm{Q}_{\mathrm{x}}$ - тепловий потік від радіатора; I - струм ТЕП; Т - температура конденсату на виході 3 конденсатора; $\mathrm{T}_{3}$ - температура конденсату в збірнику; $\mathrm{T}_{\text {нс }}$ - температура навколишнього середовища; $\mathrm{M}_{3}-$ маса конденсату в збірнику; $\mathrm{C}_{\text {в }}$ - теплоємність води; $\mathrm{C}_{\text {п }}$ - теплоємність продукту; $\mathrm{Q}_{\text {ПАРов }}$ - тепловий потік від збірника до конденсатора; f - частота обертання вакуумного насоса; fв - частота обертання вентилятора. 


\section{6. Розробка імітаційної математичної моделі процесу}

\section{1. Модель термоелектричного претворювача (ТЕП)}

Термоелектричний перетворювач є реверсивним та може працювати в режимах нагрівача, охолоджувача або електрогенератора. Зазвічай ТЕП виконують функцію охолоджувачів та/або нагрівачав і використовуються в режимі теплового насосу при цьому спостерігається ряд ефектів, які необхідно врахувати при його моделюванні Це ефекти Пельт'є, Джоуля, Томсона.

Модель ТЕП [4] складається 3 трьох джерел напруги керованих струмом та двох джерел струму керованих струмом у відповідності з рисунком 3 .

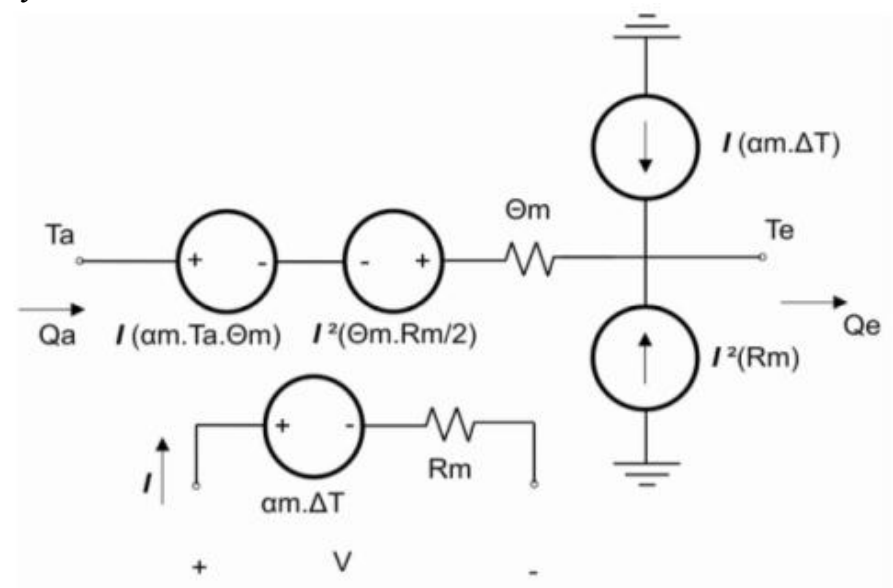

Qa - вхідний ("холодний") тепловий потік ТЕП; Qe - вихідний ("гарячий") тепловий потік ТЕП; Р - електрична потужність, яка споживається ТЕП; $\mathrm{Rm}$ - електричний опір ТЕП; $\Theta \mathrm{m}$ - тепловий опір ТЕП; $\alpha \mathrm{m}$ - коефіцієнт p-п переходу $[\mathrm{V} / \mathrm{K}]$; Те - абсолютна температура теплої сторони[K]; Та абсолютна температура холодної сторони $[\mathrm{K}]$; $\mathrm{V}$ - падіння напруги на ТЕП; I - струм крізь ТЕП.

\section{Рис. 3 - Модель елемента Пельт'є}

Вхідний "холодний" тепловий потік ТЕП розраховуватися із залежності (1).

$$
Q_{\mathrm{a}}=-\frac{\Delta \mathrm{r}}{\theta_{\mathrm{m}}}+\mathrm{am} \cdot \mathrm{Ta} \cdot \mathrm{I}-\frac{\mathbb{I}^{2} R_{\mathrm{m}}}{2}
$$

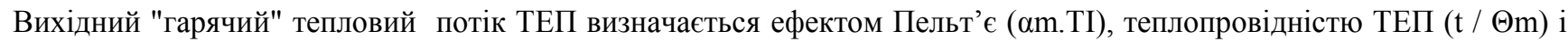
тепловим ефектом Джоуля (I² $\mathrm{Rm})$. Дію ефекту Томсона не враховуємо остільки вона незначна (2).

$$
q_{\mathrm{a}}=-\frac{\Delta \mathrm{T}}{\theta_{\mathrm{m}}}+\mathrm{am} \cdot \mathrm{Ta} \cdot \mathrm{I}+\frac{\mathrm{I}^{2} \mathrm{R}_{\mathrm{m}}}{2}
$$

Потужність, що споживає ТЕП розраховуватися із залежності (3).

$$
P=V \cdot I=I \cdot\left(a m \cdot \Delta T \cdot I+R_{m} \times I\right)
$$

Коефіцієнт продуктивності СОР характеризує ефективність роботи ТЕП (4).

$$
\mathrm{COP}=\mathrm{qa}_{\mathrm{a}} / \mathrm{P}
$$
$(5-7)$.

Параметри am, $\Theta \mathrm{m}$ i Rm можуть бути розраховані за даними технічного паспорту на ТЕП з використанням рівнянь

$$
\begin{aligned}
& R_{m}=\frac{V_{\max }}{I_{\max }} \times \frac{\left(T_{\varepsilon}-\Delta T_{\text {max }}\right)}{T_{\varepsilon}} \\
& \theta_{\mathrm{m}}=\frac{\Delta \mathrm{T}_{\max }}{\mathrm{I}_{\max } \cdot V_{\max }} \cdot \frac{2 \cdot \mathrm{T}_{\mathrm{g}}}{\left(\mathrm{T}_{\mathrm{z}}-\Delta \mathrm{T}_{\max }\right)} \\
& \mathrm{a}_{\mathrm{m}}=\frac{\mathrm{V}_{\max }}{\mathrm{T}_{\mathrm{e}}}
\end{aligned}
$$

де $\mathrm{I}_{\max }-$ максимально допустимий струм; $\mathrm{V}_{\max }$ - напруга, яка виникає на термоелементі при $\mathrm{I}_{\max } ; \Delta \mathrm{T}_{\max }-$ максимально допустима різниця температур між холодною та гарячою стороною.

Реалізуємо модель ТЕП в середовищі Matlab Simulink [5] у відповідності з рисунком 4. 


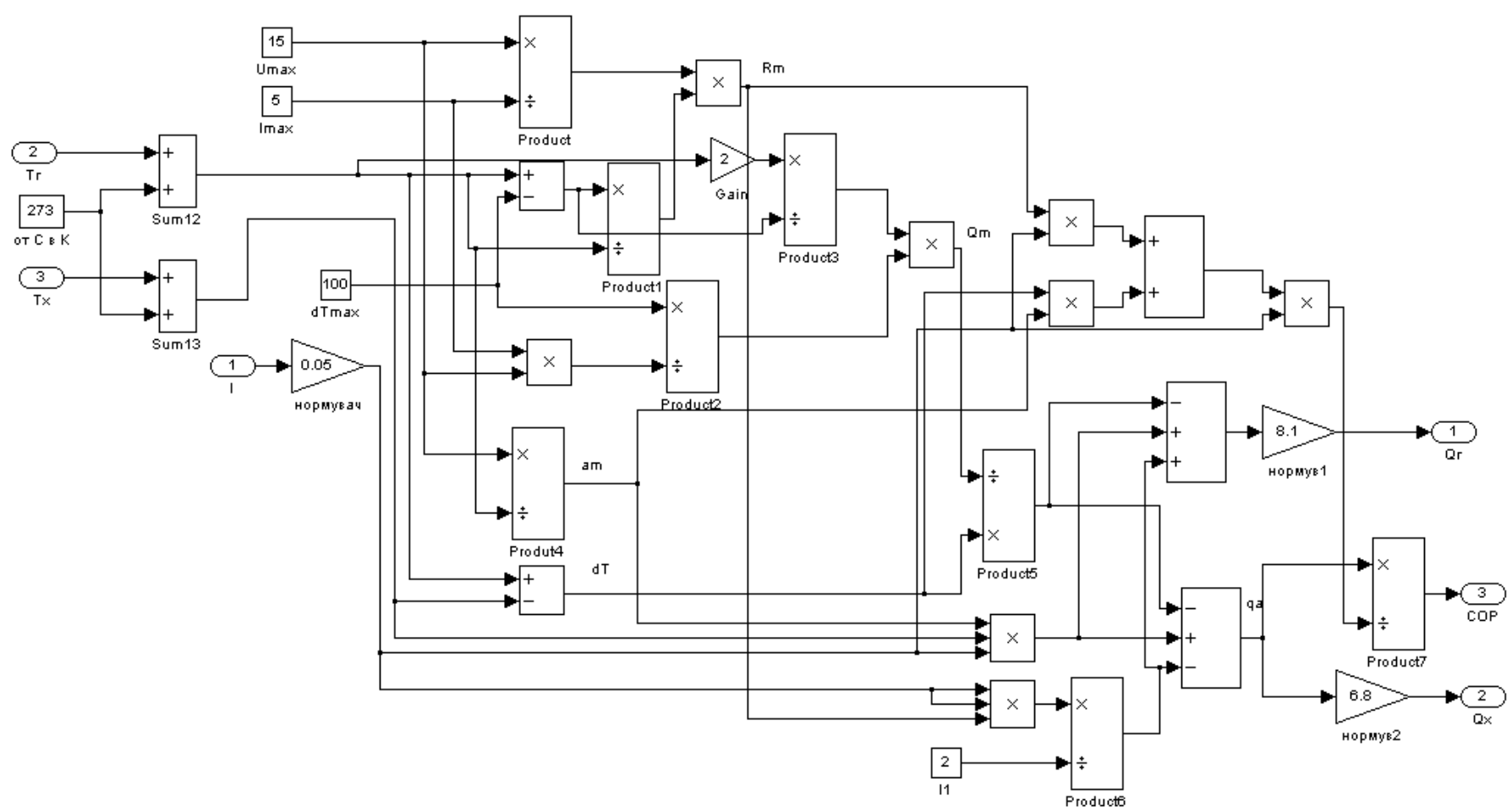

Рис. 4 - Реалізація імітаційної моделі ТЕП в середовищі Matlab Simulink

Вхідними параметрами моделі ТЕП $є$ температури холодної $\mathrm{T}_{\mathrm{X}}$ та гарячої $\mathrm{T}_{\Gamma}$ сторін, і I - струм споживання ТЕП, а також конструктивні параметри використаних елементів Пельт'е: $\Delta \mathrm{T}_{\max }, \mathrm{I}_{\max }, V_{\max }$

Вихідні параметри - "холодний" Qх та "гарячий" Qг теплові потоки ТЕП та СОР ТЕП.

\section{2. Модель пароводяної сорочки}

На рисунку 5 представлено приклад профілю зміни температури та напрямок теплового потоку при при передачі тепла через плоску розподільну стінку $[6,12,13]$.

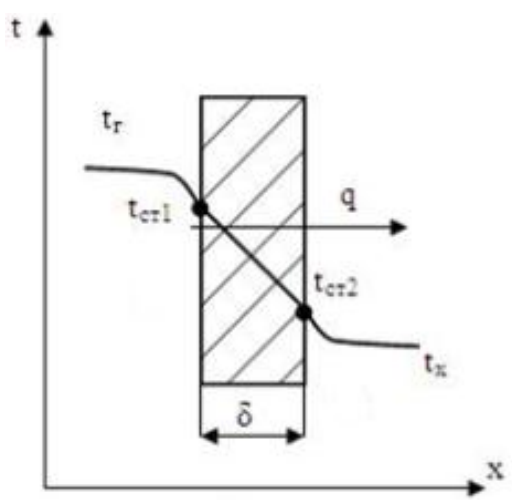

q - тепловий потік від гарячого теплоносія до холодного; tст1, tст2 - температури стінки з гарячої та холодної сторони відповідно; tг i tx - температура гарячого i холодного теплоносія відповідно; $\Delta \mathrm{t}=\mathrm{t} \Gamma-\mathrm{tx}-$ температурний напір; $\delta-$ товщина стінки

\section{Рис. 5 - Характер зміни температур в теплоносіях та стінках}

Для розрахунку теплового потоку через плоску стінку скористуємося наступною залежністю

$$
\mathrm{Q}=\mathrm{k}_{\mathrm{n}} \cdot \mathrm{F} \cdot\left(\mathrm{t}_{\mathrm{cr} 1}-\mathrm{t}_{\mathrm{cr} 2}\right)=\frac{\mathrm{\lambda}}{6} \cdot \mathrm{F} \cdot\left(\mathrm{t}_{\mathrm{cr} 1}-\mathrm{t}_{\mathrm{cr} 2}\right)
$$

де: $\lambda$ - еквівалентний коефіцієнт теплопровідності, $\mathrm{F}$ - площа поверхні плоскої стінки, $\mathrm{kn}$ - коефіцієнт теплопередачі $\mathrm{BT} /(\mathrm{M} 2 \cdot \mathrm{K})$.

Модель теплового балансу пароводяної сорочки в графічному вигляді приставлена на рисунку 6. 


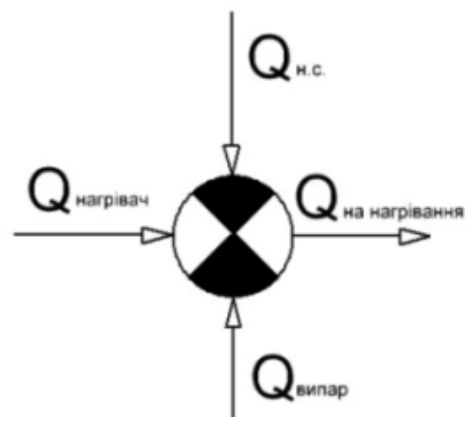

$\mathbf{Q}_{\text {нэгрівзч }}$ - підведений тепловий потік, $\mathbf{Q}_{\text {нс }}$ - втрати в навколишнє

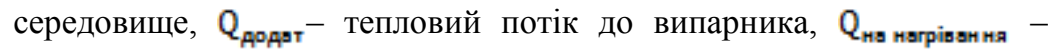
тепловий потік на нагрівання води у водяній сорочці.

Рис. 6 - Модель теплових потоків водяної (пароводяної) сорочки

Втрати в навколишнє середовище можна розрахувати, скориставшись наступною залежністю:

$$
\mathrm{QHc}=\mathrm{kF} \Delta \mathrm{t}
$$

де $\mathrm{kn}$ - середній коефіцієнт теплопередачі Вт/(м2·К); F - загальна площа поверхні теплоізоляції; $\Delta \mathrm{t}=\mathrm{tB}-\mathrm{t}$ с, $\mathrm{tв}-$ температура води у водяній сорочці; tнс - температура навколишнього середовища.

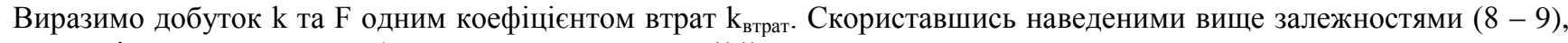
складемо рівняння теплового балансу водяної сорочки (11).

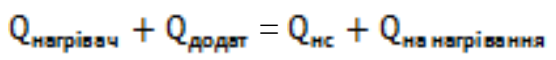

Виходячи із теплового балансу пароводяної сорочки, розрахуємо температуру води твон в ній за допомогою залежності (12):

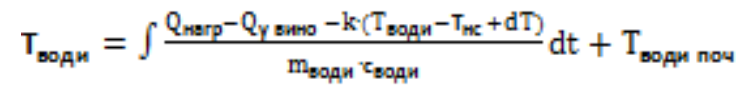

Реалізуємо модель водяної сорочки в програмі Matlab в пакеті Simulink у відповідності з рисунком 7.

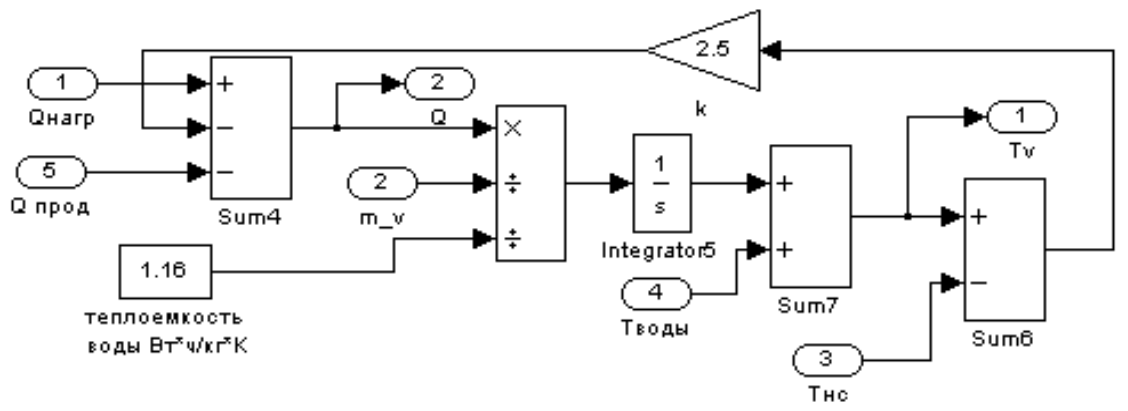

Рис. 7 - Реалізація моделі водяної сорочки в середовищі Matlab Simulink

Вхідними параметрами моделі $є$ : "гарячий" тепловий потік ТЕП $\left(\mathrm{Q}_{\text {нагр }}\right)$, різниця температур між температурою продукту та температурою води(тиском) у пароводяній сорочці (dT), температура навколишнього середовища ( $\left.\mathrm{T}_{\text {нс}}\right)$, маса води у пароводяній сорочці $(\mathrm{m})$ та іï теплоємність (c). Вихідними параметрами є температура води у водяній сорочці ( $\mathrm{T}_{\text {вода) }}$ ), та тепловий потік, який витрачається на підігрів продукту (Qпрод),

\section{3. Модель випарника}

Розглянемо спрощену модель процесу випаровування [7] у відповідності з рисунком 8.

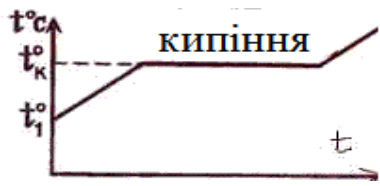

Рис. 8 - Залежність температури від часу(процес кипіння) 
В якості продукту, який знаходиться у випарнику, розглянемо суміш фруктів та сиропу. Спочатку вся енергія витрачається на підігрів продукту до температури кипіння, яка визначається тиском у випарнику, далі при сталій температурі відбувається його випаровування, після його закінчення температура почне збільшуватися, тобто енергія буде витрачатися на підігрів сухої речовини.

Розглянемо дві ділянки цієї моделі: підігрів бінарної суміші до температури кипіння та ії випаровування. Модель зміни температури продукту у випарнику представлена наступною системою рівнянь (14).

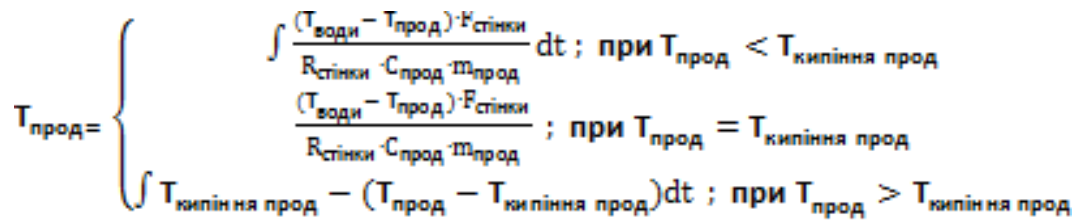

Модель зміни теплового потоку, який витрачається на випаровування продукту з фруктів та сиропу, представлена залежністю (15).

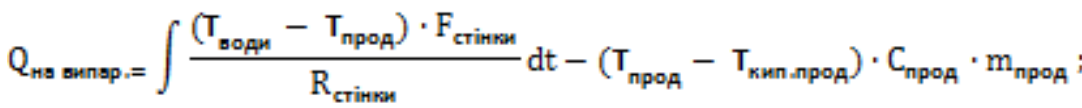

$$
\begin{aligned}
& \text { при } T_{\text {прод }} \geq T_{\text {кипіння прод }}
\end{aligned}
$$

Модель зміни витрат випарюваної води представлена залежністю (16).

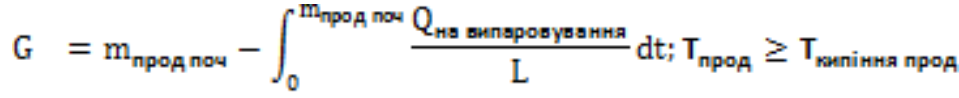

$$
\begin{aligned}
& \text { звідки } \quad \mathrm{m}_{\text {прод пон }}=\left(\mathrm{m}_{\text {mpод }}-\% \mathrm{~m}_{\text {води }} \times \mathrm{m}_{\text {прод }}\right) \cdot \mathrm{p}
\end{aligned}
$$

Реалізуємо модель випарника в програмі Matlab в пакеті Simulink у відповідності з рисунком 9.

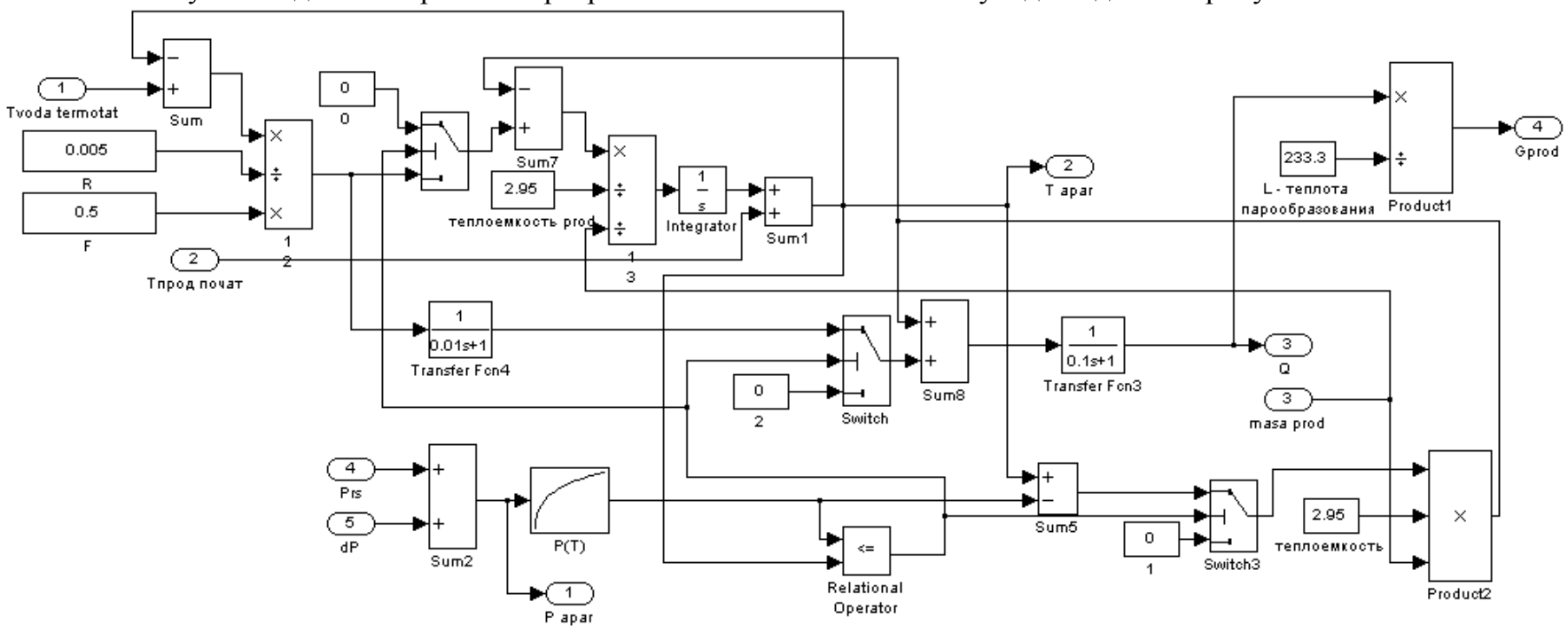

Рис. 9 - Реалізація моделі випарника в середовищі Matlab Simulink

Вхідними параметрами моделі випарника є: температура води у водяній сорочці (Т вода), початкова температура продукту $\left(\mathrm{T}_{\text {продпоч}}\right)$, розрідження в ресивері (Рpec) та перепад розрідження на паропроводі(dP), площа підігріву випарника $(\mathrm{F})$ та тепловий опір матеріала, з якого вона виготовлена $(\mathrm{R})$, початкова маса продукту (m прод) та концентрація сухих речовин ньому (\%.c.p). Вихідними параметрами моделі випарника $є$ : температура продукту (T прод), тиск у випарнику(Papar) витрати пари з випаника (Gп,).

\section{4. Модель паропроводу}

Гідравлічний опір в трубопроводах - опір руху рідин (газів), який чиниться на ділянці трубопроводу, оцінюється величиною "втраченого" тиску $\Delta \mathrm{P}$, що представляє собою частину питомої енергії потоку, яка необоротно витрачається на роботу сил опору. При сталому перебігу рідини (газу) у трубопроводі круглого перерізу $\Delta$ р (н/м2) визначається за формулою (18) $[9,10]$.

$$
\Delta \mathrm{P}=\lambda \frac{\mathrm{u}^{2} \mathrm{~L}}{2 \mathrm{D}} \cdot \mathrm{\rho}
$$


де $\lambda$ - коефіцієнт гідравлічного опору трубопроводу; u - швидкість потоку (м/с); D - внутрішній діаметр трубопроводу, м; L - довжина трубопроводу, м; $\rho$ - густина рідини, кг/м3.

Реалізуємо модель паропроводу від випарника до конденсатора в середовищі Matlab Simulink у відповідності 3 рисунком 10.

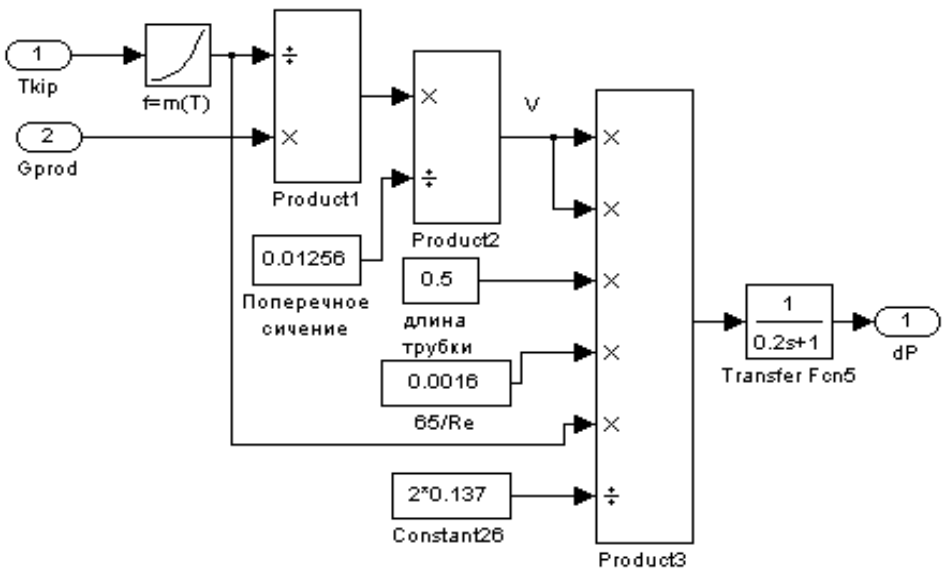

Рис. 10 - Реалізація моделі паропроводу в середовищі Matlab Simulink

Вхідними параметрами моделі $є$ температура сокових парів ( $\left.\mathrm{T}_{\text {пара }}\right)$, масові витрати пари. Вихідними параметрами моделі $є$ перепад тиску $(\Delta \mathrm{P})$ в паропроводі.

\section{5. Модель конденсатора}

Для побудови моделі конденсатора скористуємося залежностями (2.4) та (2.8). Модель теплових потоків конденсатора зображено на рисунку 11.

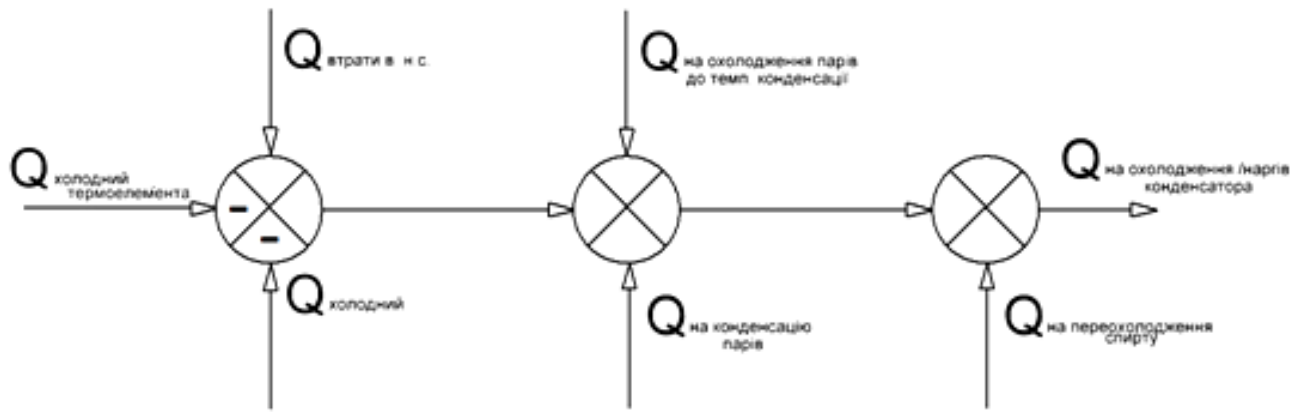

Рис. 11 - Модель теплових потоків конденсатора

Реалізація моделі конденсатора в середовищі Matlab Simulink представлена на рисунку 12.

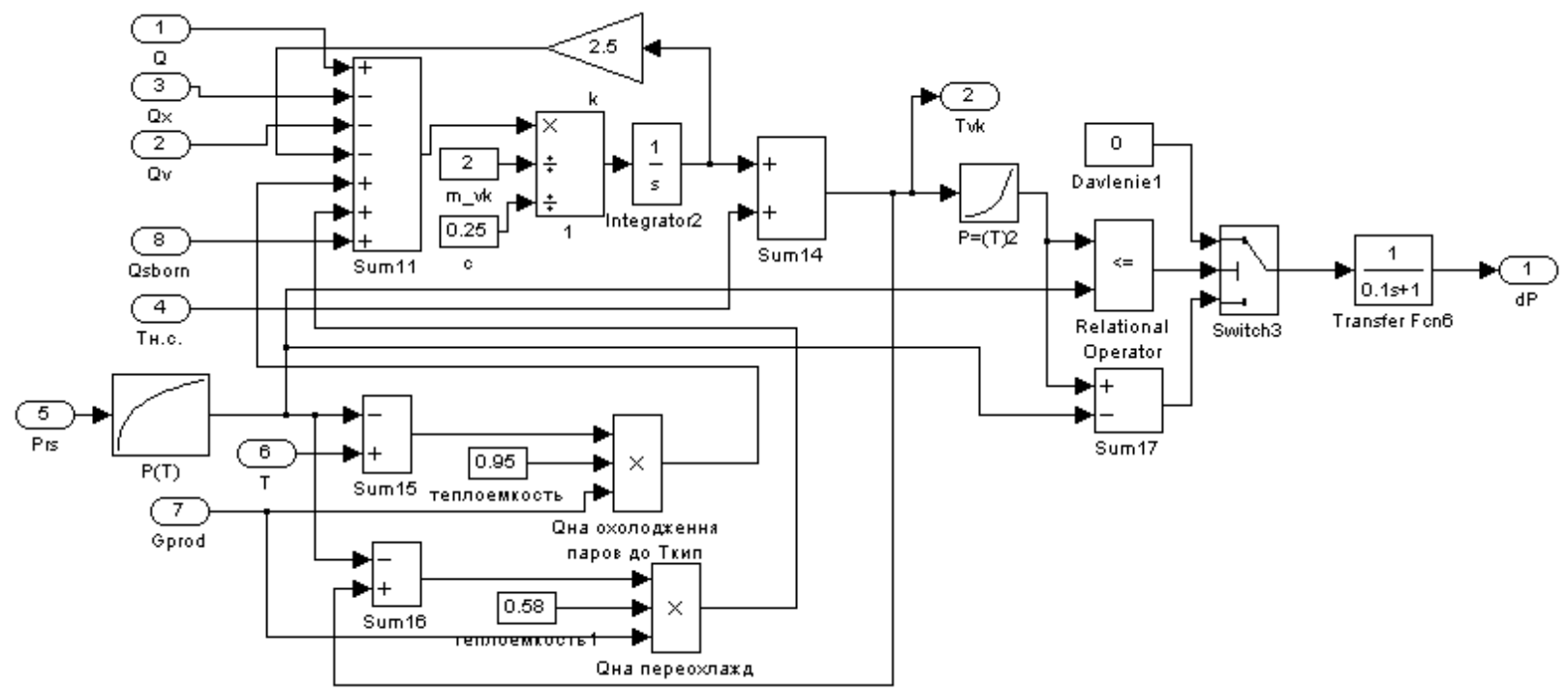

Рис. 12 - Модель конденсатора в програмі Matlab в пакеті Simulink 
Вхідними параметрами моделі є тепловий потік сокових парів ( $\left.\mathrm{Q}_{\text {паров}}\right)$, «холодні» теплові потоки від ТЕП та

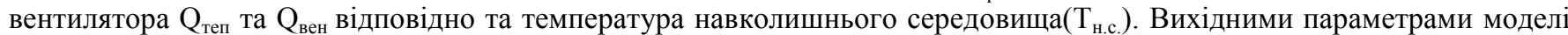
$€$ : температура( тиск) конденсації пари та різниця між тискомь(температурою) конденсації пари та тиском у ресивері.

\section{6. Модель вакуумної системи}

Для побудови моделі скористуємось рівнянням стану ідеального газу. [10]

$$
p V=\frac{m}{M} R T
$$

Оскільки всі процеси досить інерційні, припустимо, що вакуумний насос (BН) безінерційний та виходячи із його конструкції та ємності вакуумної системи, опишемо процес відкачування повітря (зміну тиску в системі) залежністю (2.20).,

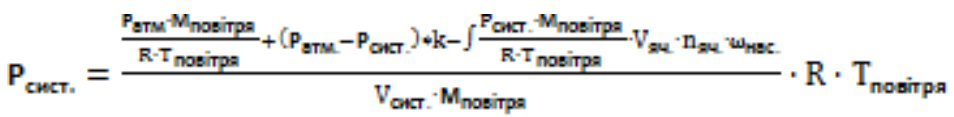

де Ратм - атмосферний тиск; Рсист. - тиск в вакуумній системі; М - молярна маса повітря; Vсист. - об'єм вакуумної системи; Vяч. - об'єм робочої камери ВН; Тповітря - абсолютна температура повітря; R - універсальна газова стала; $\mathrm{k}$ - коефіцієнт підсосу повітря.

Реалізуємо модель вакуумної системи відповідності з рисунком 13.

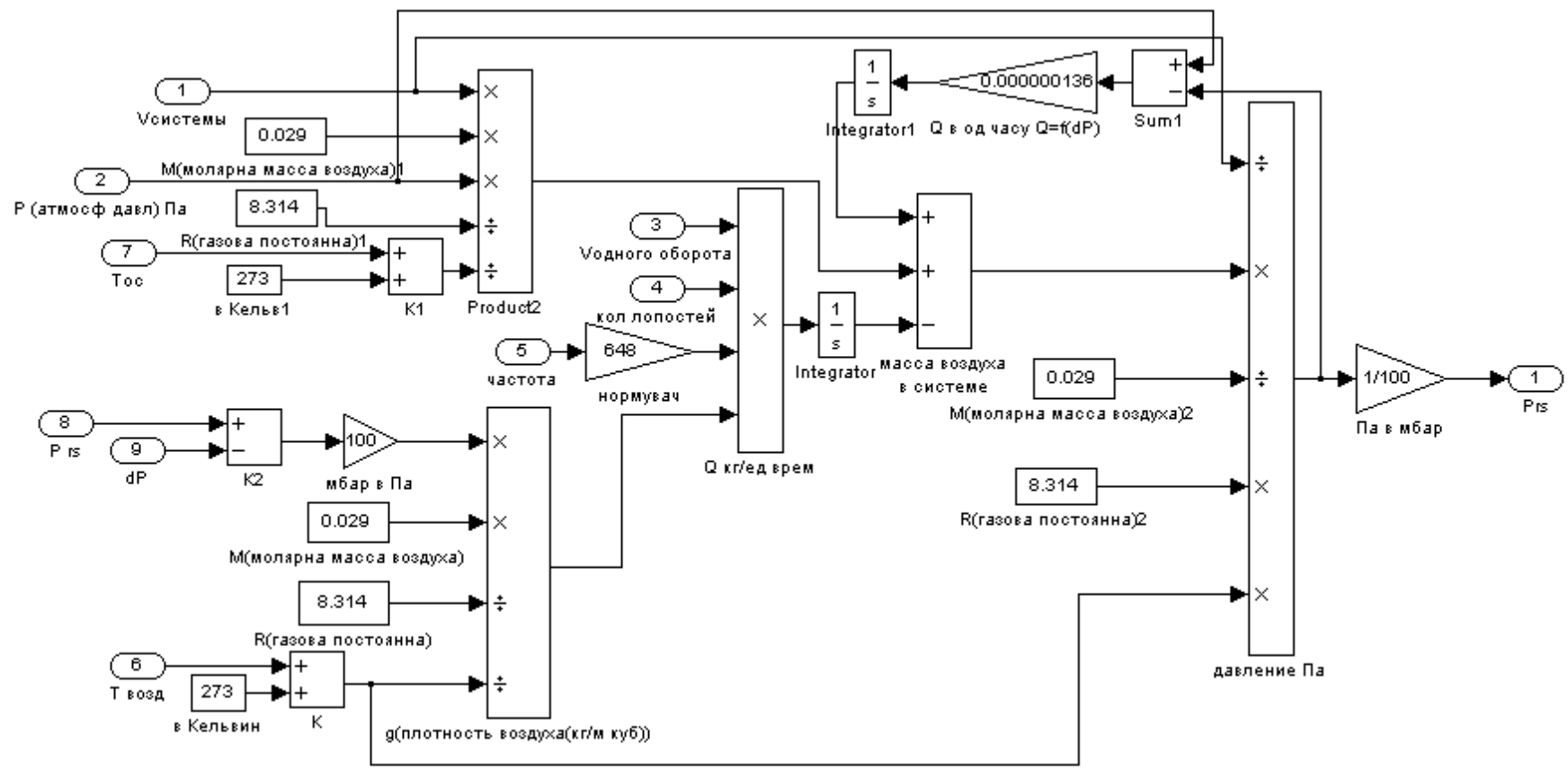

Рис. 13 - Реалізація моделі зміни тиску в системі в середовищі Matlab Simulink

\section{7. Модель збірника конденсату}

Для побудови моделі використуємо рівняння стану ідеального газу (19) та залежності, які дозволять розрахувати енергію, що витрачається на підігрів речовини до температури кипіння (4), та на часткове випаровування конденсату (15), розрахувати зміну температури у збірнику за рахунок потрапляння в нього переохолодженого конденсату [6,10].

Необхідно також розрахувати зміну температури у збірнику за рахунок потрапляння в нього переохолодженого конденсату врахуванням "аварійного" режиму роботи, коли температура конденсату в збірнику вище ніж точка його кипіння та витрати енергії, яка буде використовуватися для охолодження парів, що прямують від збірника. Опишемо збірник конденсату наступними системами рівнянь (21 - 23).

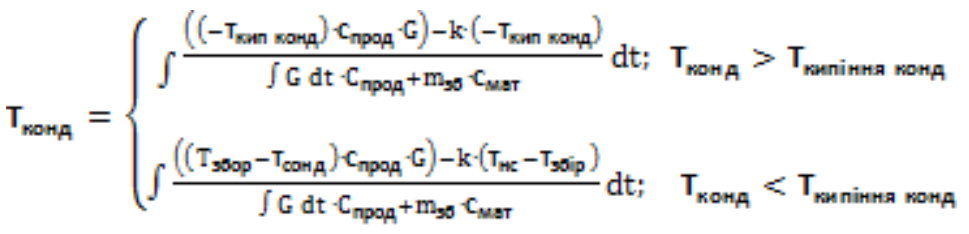

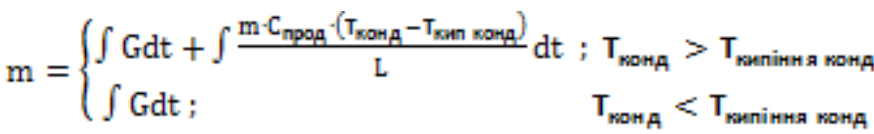



http://www.atbp.onaft.edu.ua/

$$
\mathrm{Q}= \begin{cases}\int \mathrm{m} \cdot \mathrm{C}_{\text {прод }} \cdot\left(\mathrm{T}_{\text {конд }}-\mathrm{T}_{\text {кип конд }}\right) \mathrm{dt} ; & \mathrm{T}_{\text {конд }}>\mathrm{T}_{\text {кипіння конд }} \\ 0 ; & \mathrm{T}_{\text {конд }}<\mathrm{T}_{\text {киніння конд }}\end{cases}
$$

де $\mathrm{T}_{\text {кипконд }}$ - температура кипіння конденсату; $\mathrm{m}$ - маса конденсату в збірнику; Q - енергія парів продукту; $\mathrm{M}$ молярна маса; $\mathrm{V}_{\text {сист }}$ - об'єм системи; $\mathrm{T}_{\text {конд }}$ - температура конденсату; $\mathrm{R}$ - універсальна газова стала; $\mathrm{G}$ - витрати

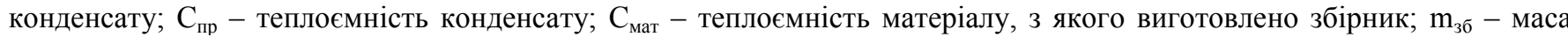
матеріалу, з якого виготовлено збірник; $\mathrm{k}$ - коефіцієнт теплових втрат в навколишнє середовище.

Реалізуємо модель збірника конденсату в середовищі Matlab Simulinky відповідності з рисунком 14.

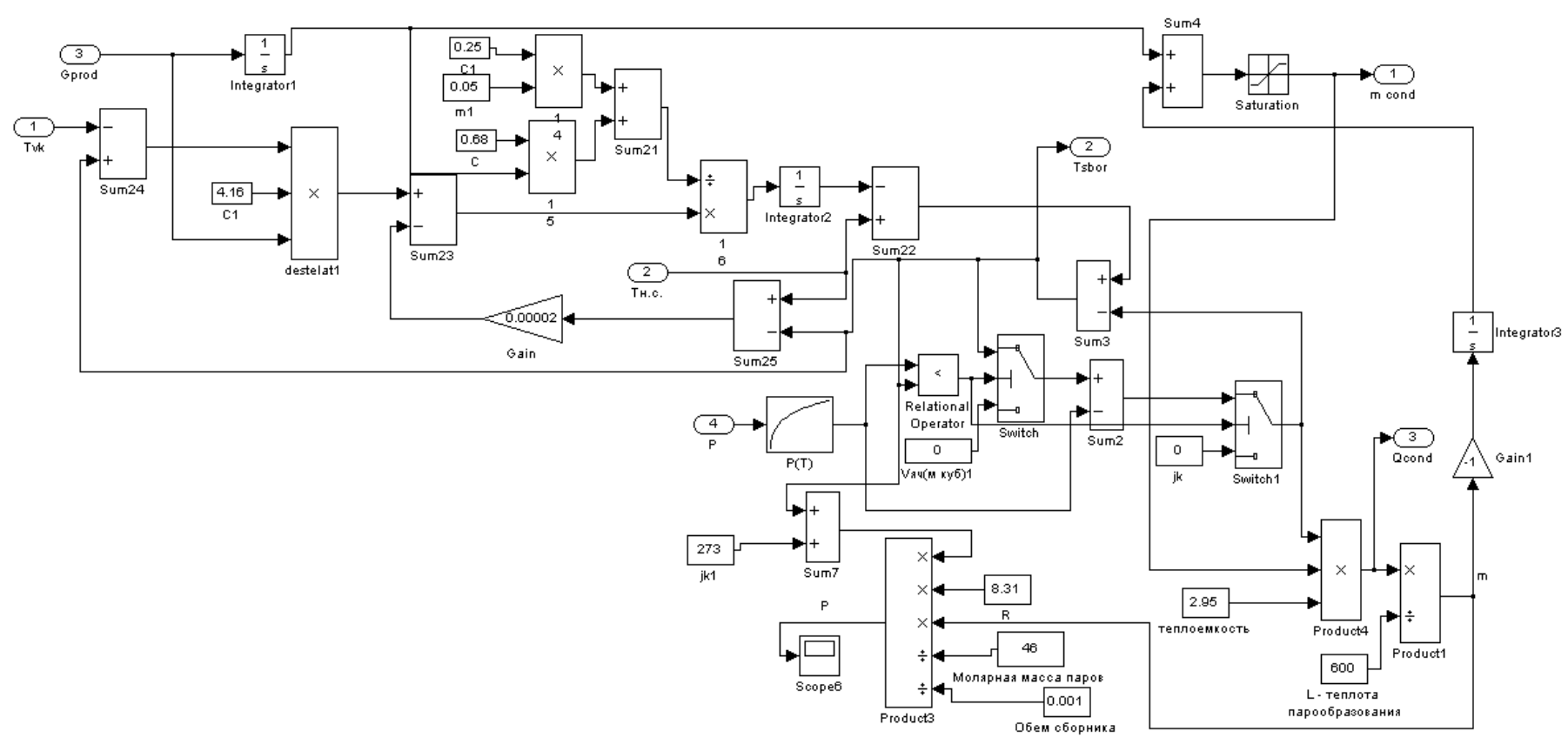

Рис. 14 - Реалізація моделі збірника конденсату в середовищі Matlab Simulink

\section{8. Модель радіатора $з$ повітряним охолодженням}

Для побудови моделі радіатора будемо користуватися залежностями (4) та (8).

Реалізуємо модель в програмі Matlab в пакеті Simulink у відповідності з рисунком 15.

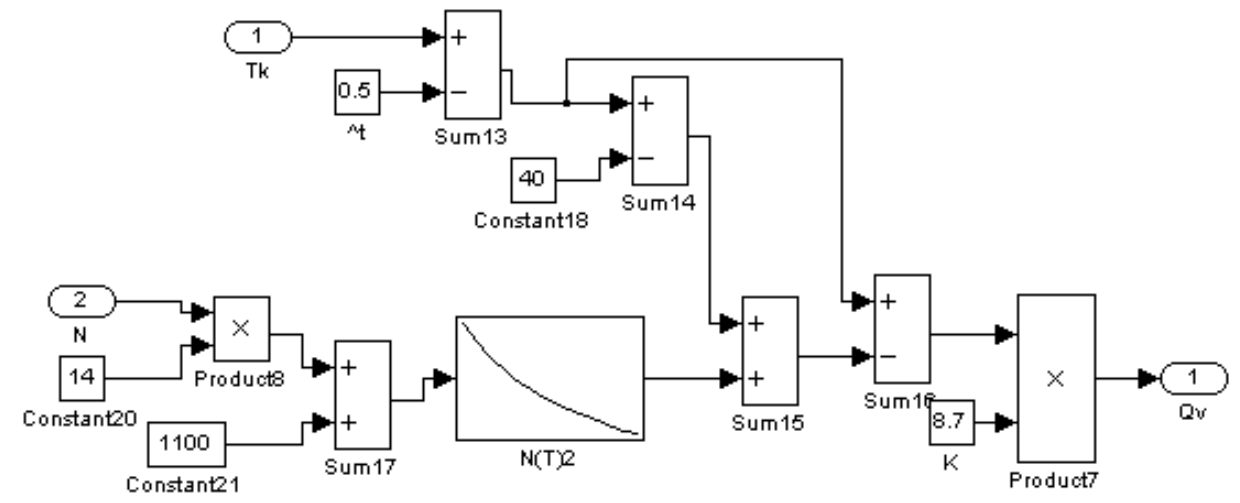

Рис. 15 - Реалізації моделі радіатора $з$ повітряним охолодженням в середовищі Matlab Simulink

Вхідними параметрами моделі є температура конденсатора (Тк), кількість обертів вентилятора (N), температура навколишнього середовища, площа $(\mathrm{F})$ та кількість $(\mathrm{N})$ секцій радіатора. Вихідним - тепловий потік, що охолоджує воду в конденсаторі $\left(\mathrm{Q}_{\mathrm{V}}\right)$.

\section{9. Загальна імітаційна модель процесу}

Виходячи із загальної структурної схеми імітаційна модель процесу в середовищі Matlab Simulink складеться 3 моделей окремих вузлів, а саме: термоелектричного перетворювача, пароводяної сорочки, випарника, паропровода, конденсатора і моделі вакуумної системи з ресивером та вакуумним насосом, з'єднаних необхідними зв’язками у відповідності з рисунком 16. Комплекс імітаційних моделей було максимально спрощено, оскільки він розроблявся 
не для розрахунку конструктивних параметрів вузлів та агрегатів, а для дослідження процесу як об'єкту керування, і його основна задача адекватно відтворювати фізичні властивості та взаємозв'язки між основними змінними процесів в МВТК. Так у випарнику та конденсаторі прийнята модель ідеального перемішування, перепад температур (тиску) в теплових трубах та в пароводяній сорочці відсутній і т.д.

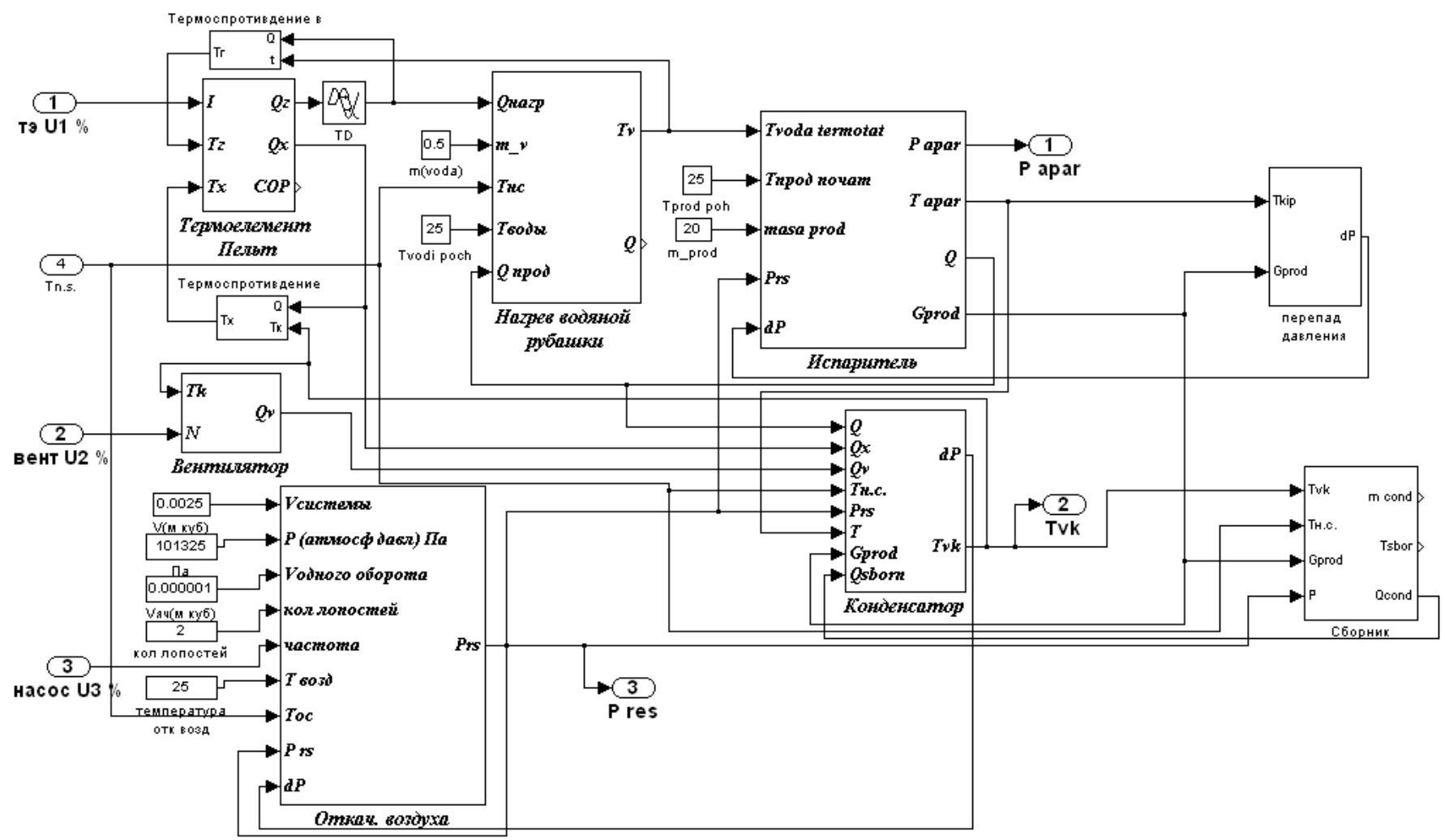

Рис. 16 - Реалізація загальної імітаційної моделі процесу термовакуумної обробки харчових продуктів в середовищі Matlab Simulink

\section{7. Дослідження імітаційної моделі процесу та перевірка її на адекватність}

3 метою дослідження статичних та динамічних властивостей отриманої імітаційної моделі МВТК та перевірки моделі на адекватність, були організовані експерименти, які можна розглядати як отримання сімейств квазістатичних залежностей між основними змінними процесу $[8,9,13]$. Для цього в процесі моделювання були використані декілька паралельно працюючих моделей. При тому один з вхідних параметрів процесу, в майбутньому можливо керуючий вплив, змінювався в заданому діапазоні з постійною попередньо вибраною швидкістю на входах всіх паралельно працюючих моделей, а декілька різних фіксованих значень другого вхідного параметру подавались одночасно на відповідні входи цих моделей. При цьому проводилась реєстрація необхідних змінних процесу. Наприклад, величина струму ТЕП змінюється з постійною швидкістю від 0-10А (0 - 100\%х.р.о.) і моделювання їде при різних фіксованих частотах обертання вентилятора від 0 до 2400 об/хв (0 - 100\%х.р.о.) 3 реєстрацією основних змінних процесу: тиск у випарнику (Рпр), температура води в конденсаторі (Твк), розрідження в ресивері (Р рес). і т.д. Результати такого машинного експерименту представлені на рисунках 17 та 18.

Характер цих залежностей свідчить про те, що температура у випарнику визначається перед усім температурним режимом конденсатора та перепадом тиску в паропроводі, який, в свою чергу, залежить від витрати пари крізь паропровід. Таким чином, керувати швидкістю випаровування можливо, контролюючи перепад тиску в паропроводі. Дуже суттєвий вплив на сталі температурні режими процесу термовакуумної обробки, при інших рівних умовах, мають як рівень струму ТЕП, так і частота обертання вентилятора. При збільшені потужності ТЕП необхідно також збільшити потужність вентилятора, щоб іiі вистачало для виходу на заданий температурний режим конденсатора. Необхідно також враховувати, що при повній потужності ТЕП тиск насичених парів дистиляту, відповідній до температури конденсації, не повинен перевищувати тиск неконденсованих газів в вакуумній системі, що може привести до "аварійних" режимів. Наявність таких режимів на рисунках 17-18 спостерігається при частотах обертів вентилятора менших 30\% від максимальних.

На рисунку 19а представлені динамічні залежності тиску у випарнику при ступінчатій зміні струму ТЕП для різних частот обертів вентилятора. 3 огляду на них, можливо зробити висновок, що вибрана потужність ТЕП замала. Для більш швидкого виходу на режим можливо або збільшити потужність ТЕП, або зменшити масу продукту. 

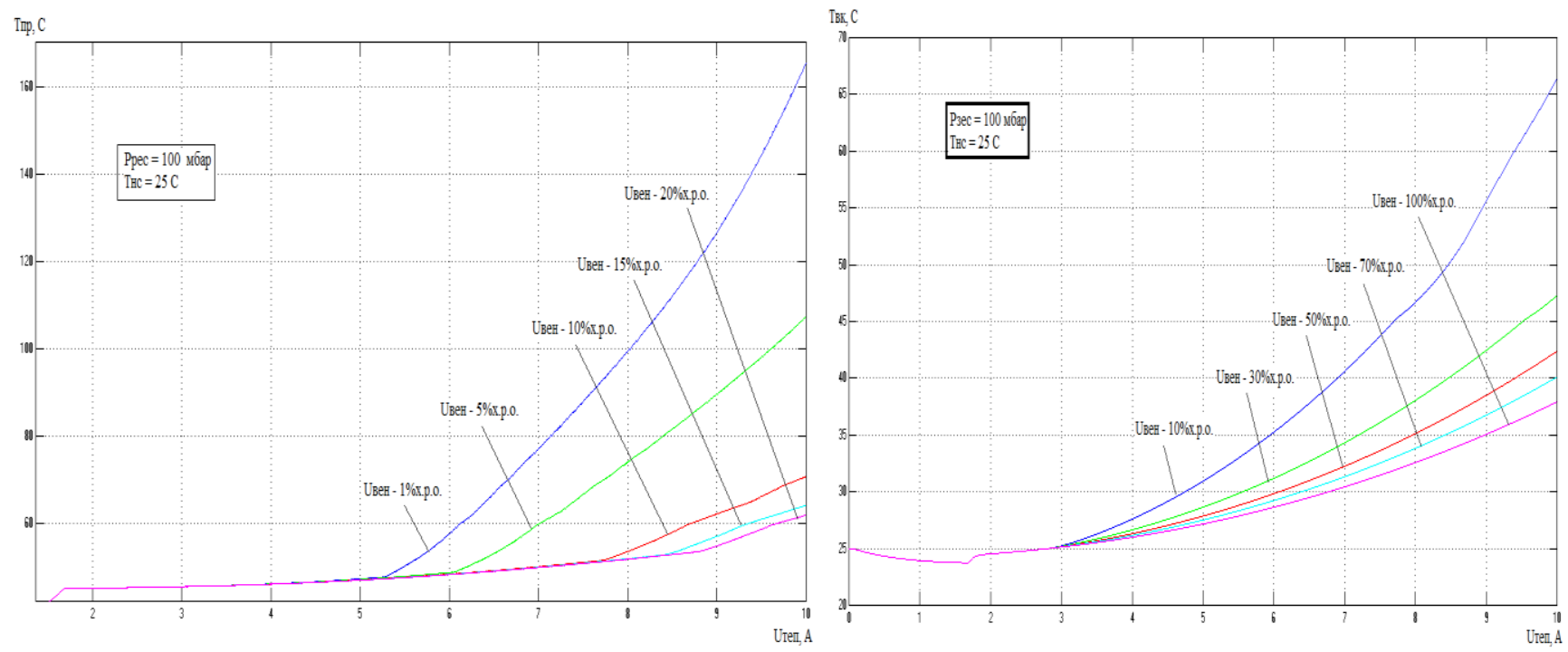

Рис. 17 - Квазістатичні залежності температури у випарнику(а) та температури конденсатора (б) від струму ТЕП при різних частотах вентилятора

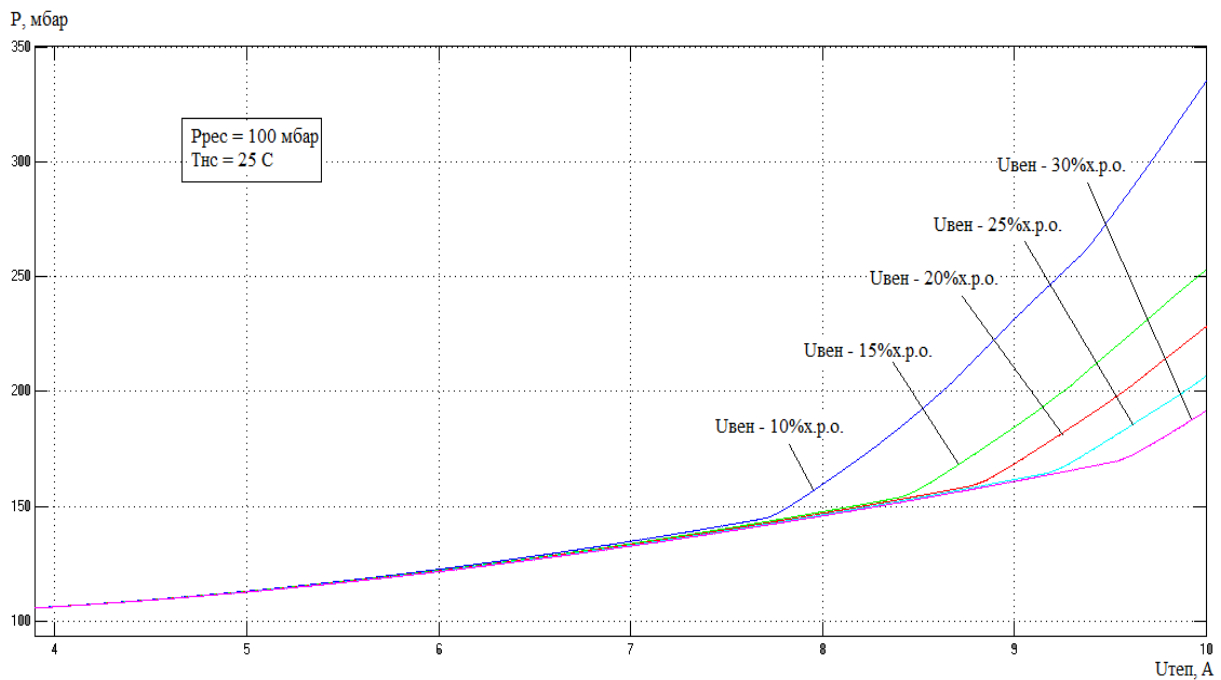

Рис. 18 - Квазістатичні залежності тиску у випарнику від струму ТЕП при різних частотах вентилятора

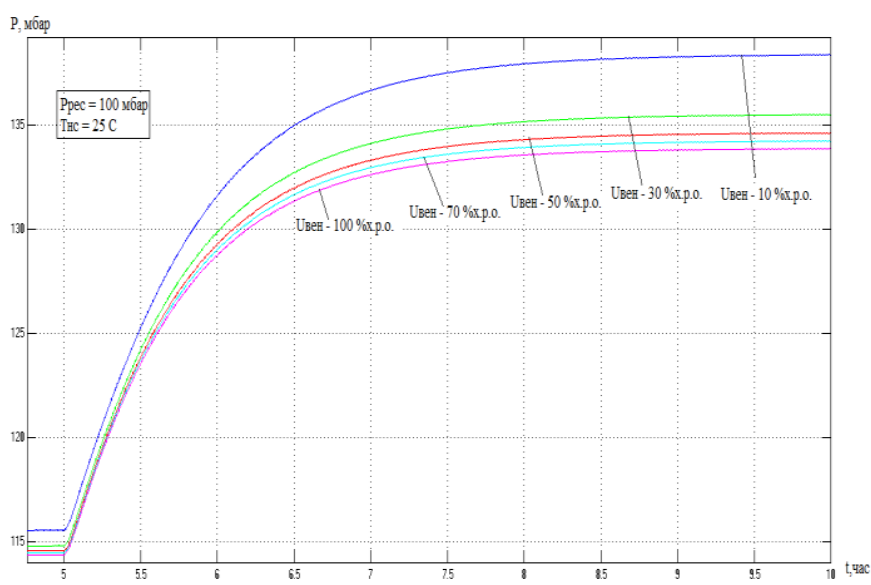

a)

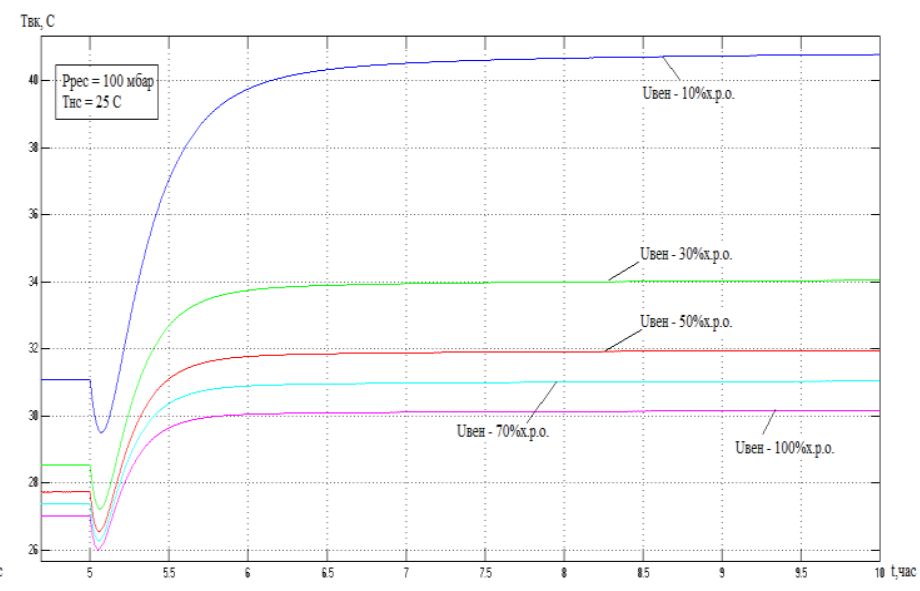

б)

Рис. 19 - Динамічні залежності тиску у випарнику(а) та температури конденсатора (б) при ступінчатій зміні струму ТЕП для різних частот обертів вентилятора 
http://www.atbp.onaft.edu.ua/

На рисунку 196 представлені динамічні залежності температури води в конденсаторі при ступінчатому збільшенню струму ТЕП для різних частот обертів вентилятора. 3 графіків на рисунку 196 видно, що після ступінчатого збільшення струму ТЕП, температура води в конденсаторі спочатку зменшується, а потім зростає. Це обумовлюється тим, що при збільшенні рівня струму потужність ТЕП та його "холодний" тепловий потік охолоджуючий конденсатор зростає, і температура води в конденсаторі спочатку спадає, але 3 часом за рахунок інтенсифікації кипіння у випарнику та збільшенню кількості пари, що конденсується, вона знову зростає відповідно до сталого режиму. Така поведінка імітаційної моделі свідчить про те, що вона досить адекватно відтворює не тільки статичні, а і динамічні властивості тепломасообмінних процесів, що протікають в МВТК.

\section{8. Висновки}

Результати тестування статичних та динамічних властивостей розробленої аналітичної імітаційної моделі свідчать про те, що вона доволі адекватно відтворює складні тепломасообмінні процеси, які протікають в малогабаритному вакуумному термоелектричному котлоагрегаті, і може бути використана при дослідженні його як об'єкту керування, а також при розробці та тестуванню алгоритмів керування процесом.

\section{Список використаних джерел}

[1] ДСТУ 3862-99 Ресторанне господарство. Терміни та визначення

[2] Научные основы производства продуктов питания: учебное пособие для высшего профессионального образования / С.Я. Корячкина, О.М. Пригарина. - Орел: ФГБОУ ВПО «Госуниверситет-УНПК», 2011. - 377 с.

[3] Hudz, S., Mazur, A., \& Kovalchuk, D.. The thermoelectric vacuum crock-pot and the automated workplace for its research as a control object. Automation of Technological and Business Processes, 9(2).

[4] Chakib Alaoui, "Peltier Thermoelectric Modules Modeling and Evaluation", International Journal of Engineering, KSA, vol. 5, no. 1, pp. 114-121,Sep 2011.

[5] https://www.mathworks.com/help/simulink/

[6] Касаткин, А. Г. Основные процессы и аппараты химической промышленности.М.: Госхимиздат 1971.

[7] Гальперин Н.И. Выпарные аппараты - Москва: Госхимиздат, тип. им. Евг.Соколовой: 2-я типолит. ГИМИЗ в Ленинграде,1947. - 380 с : ил.,1 л. граф.

[8] Ковальчук Д. А., Мазур О. В., Хобін В. А. Дослідження процесів утилізації тепла пароповітряних сумішей:результати експериментів, структурна та параметрична ідентифікація основних каналів об'єкту //Automation of technological and business processes. -2019. -T. 11, no. 1

[9] Ковальчук, Д., \& Мазур, О.. Дослідження процесів утилізації тепла пароповітряних сумішей: імітаційне моделювання. Automation of Technological and Business Processes, 11(4), 68-82. https://doi.org/10.15673/atbp.v11i4.1601

[10] Злобин В.Г., Горбай С.В., Короткова Т.Ю. Техническая термодинамика. Часть 1. Основные законы термодинамики. Циклы тепловых двигателей: учебное пособие. -2 изд., испр. и перераб./ВШТЭ СПбГУПТД. СПб., 2016.-146 с.: ил. 52.

[11] Энергоэффективное гарантирующее управление тепловыми и тепло-массообменными процессами пищевых технологий: проблемы, имитационные модели, структуры и алгоритмы САУ [Текст] : монография / Хобин В. А., Мазур А. В., Степанов М. Т. - Херсон : Гринь Д. С. [изд.], 2014. - 212 с. : рис., табл. - Бібліогр.: с. 203-210. - 300 прим. - ISBN 978-617-7123-95-7

[12] Мазур, А. В. Повышение энергетической эффективности тепловых процессов пищевых технологий средствами гарантирующего управления [Текст] : дис... канд. техн. наук: 05.13.07 / Мазур Александр Васильевич ; Одесская национальная академия пищевых технологий. - О., 2006. - 208 л.: рис., табл. - Библиогр.: л. 167-178

[13] Мазур О.В., Степанов М.Т. Моделювання процесів управління пастеризаційно-охолоджувальною установкою у середовищі MATLAB // Наук. пр. ОДАХТ / Міністерство освіти України. - Одеса: 2001. - Вип. 22. - С. 124-128.

\section{References}

[1] DSTU 3862-99 Restoranne gospodarstvo. termini ta viznachennya

[2] Koryachkina S.Ya., Prigarina O.M. Nauchnyie osnovyi proizvodstva produktov pitaniya: uchebnoe posobie dlya vyisshego professionalnogo obrazovaniya. Orel: FGBOU VPO Gosuniversitet-UNPK, 2011, 377 p.

[3] Hudz, S., Mazur, A. And Kovalchuk, D. "The thermoelectric vacuum crock-pot and the automated workplace for its research as a control object", Automation of technological and business processes, 9(2), 2017

[4] Chakib Alaoui, "Peltier Thermoelectric Modules Modeling and Evaluation", International Journal of Engineering, KSA, vol. 5, no. 1, pp. 114-121, Sep. 2011.

[5] Simulink [Electronic source]. Available at https://www.mathworks.com/help/simulink/

[6] Kasatkin, A. G. Osnovnyie protsessyi i apparatyi himicheskoy promyishlennosti. Moscow, Goshimizdat, 1971.

[7] Galperin, N.I. Vyparnyie apparaty. Moskva, Goshimizdat, 1947, 380 p.

[8] Kovalchuk, D.A., Mazur, O.V., Khobin, V.A. "Doslidzhennya protsesIv utilizatsiyi tepla paropovitryanih sumishey:rezultati eksperimentiv, strukturna ta parametrichna identifikatsiya osnovnih kanaliv ob'ektu", Automation of technological and business processes, 2019, 11(1) 
[9] Kovalchuk, D., \& Mazur, O. "Doslidzhennya protsesiv utilizatsiyi tepla paropovitryanih sumishey: imitatsiyne modelyuvannya". Automation of technological and business processes, 11(4), 68-82. https://doi.org/10.15673 /atbp.v11i4.1601

[10] Zlobin V.G., Gorbay S.V., Korotkova T.Yu. Tehnicheskaya termodinamika. Chast 1. Osnovnyie zakonyi termodinamiki. Tsiklyi teplovyih dvigateley: uchebnoe posobie.-2 izd., ispr. i pererab. VShTE SPbGUPTD. 2016.

[11] Hobin V. A., Mazur A. V., Stepanov M. T. Energoeffektivnoe garantiruyuschee upravlenie teplovyimi $i$ teplomassoobmennyimi protsessami pischevyih tehnologiy: problemyi, imitatsionnyie modeli, strukturyi $i$ algoritmyi SAU : monografiya. Kherson,Grin D. S., 2014, 212 p. ISBN 978-617-7123-95-7

[12] Mazur, A. V. Povyishenie energeticheskoy effektivnosti teplovyih protsessov pischevyih tehnologiy sredstvami garantiruyuschego upravleniya : dis... kand. tehn. nauk: 05.13.07. Odesskaya natsionalnaya akademiya pischevyih tehnologiy. 2006.

[13] Mazur O.V., Stepanov M.T. "Modelyuvannya protsesIv upravlInnya pasterizatsIyno-oholodzhuvalnoyu ustanovkoyu u seredovischI MATLAB” Nauk. pr. ODAHT, 22, pp. 124-128, 2001. 